\title{
Pelatihan Budidaya Jamur Tiram Untuk Mahasiswa Tadris Biologi Sebagai Pendukung Matakuliah Bioteknologi dan Kewirausahaan Biologi
}

\author{
Meyninda Destiara ${ }^{1}$, Nurul Himmah ${ }^{2 *}$, Istiqamah ${ }^{3}$ \\ ${ }^{1,2,3}$ Program Studi Tadris Biologi, Fakultas Tarbiyah dan Keguruan, UIN Antasari Banjarmasin, \\ Banjarmasin, Indonesia \\ Email: ${ }^{1}$ meyninda.destiara@uin-antasari.ac.id, ${ }^{2 *}$ nurulhimmah@uin-antasari.ac.id, \\ 3istiqamah@uin-antasari.ac.id
}

\begin{abstract}
Oyster mushrooms (Pleurotus ostreatus) are one of the products related to conventional biotechnology where the product is a food that can be consumed. So that in the application of training in the cultivation of Oyster mushrooms is concerned about biotechnology and entrepreneurship subjects. Along with the rise of covid-19 that occurs is not a barrier to the facilitator team in performing devotion, of course with a limited scale. The devotion that is carried out is (1) Counseling, conducted online with online webinars followed by all biology students and participants from the general public. (2) Preparation, establishing a committee for advanced activities, namely training in oyster mushroom cultivation and implementation in entrepreneurship (3) Implementation of stage 1, implementation of oyster mushroom cultivation and implementation of biotechnology subjects, (4) Implementation of stage 2, implementation of biological entrepreneurship subjects by selling biologically efficacious products such as raw oyster mushrooms, (5) Monitoring and evaluation of activities: monitoring and evaluation of activities carried out by the Committee and facilitators as parties who help monitoring and evaluation which are also assisted by sources.
\end{abstract}

Keywords: Cultivation, Oyster Mushroom, Entrepreneurship Biology.

\begin{abstract}
Abstrak
Jamur tiram (Pleurotus ostreatus) merupakan salah satu produk yang berkaitan dengan bioteknologi konvensional yang mana produknya merupakan sebuah pangan yang dapat dikonsumsi. Sehingga pada penerapan pelatihan budidaya jamur tiram ini menyangkut tentang matakuliah bioteknologi dan kewirausahaan. Seiring dengan maraknya covid-19 yang terjadi tidak menjadi penghalang tim fasilitator dalam melaksankan pengabdian, tentu dengan skala terbatas. Kegitan pengabdian yang dilaksanakan yaitu (1) Penyuluhan, dilaksanakan secara daring dengan webinar online dengan diikuti Semua mahasiswa tadris biologi dan peserta dari masyarakat umum. (2) Persiapan, melakukan pembentukan panitia untuk kegiatan lanjutan yaitu pelatihan budidaya jamur tiram dan implementasi dalam kewirausahaan (3) Pelaksanaan tahap 1, pelaksanaan budidaya jamur tiram serta pengimplementasian matakuliah bioteknologi (4) Pelaksanaan tahap 2, pengimplementasian matakuliah kewirausaahaan biologi dengan menjual produk berkhas biologi yaitu seperti jamur tiram mentah, (5) Monitoring serta evaluasi kegiatan: monitoring serta evaluasi kegiatan yang dilakukan oleh Panitia dan fasilitator sebagai pihak yang membantu pendampingan memonitoring serta evaluasi yang juga dibantu narasumber.
\end{abstract}

Kata Kunci: Budidaya, Jamur Tiram, Kewirausahaan Biologi.

\section{A. PENDAhULUAN}

Jamur tiram merupakan pangan bergizi yang minati orang-orang sebagai tambahan lauk pada saat makan. Menurut alex (2011), jamur tiram putih (Pleourotus ostreatus var florida) merupakan makanan yang aman untuk dikonsumsi dan tidak beracun sehingga dapat dikonsumsi Berdasarkan penelitian Donowati, dkk (2015) produk jamur tiram (Pleurotus ostreatus) merupakan makan sehat yang dapat disamaratakan kelezatannya dengan daging ayam untuk bahan dasar burger. Sehingga pada penelitian Muchtadi (2010) menyimpulkan bahwa jamur tiram memiliki protein tinggi 17,5\% - 27\% dengan lemak 
yang rendah yaitu 1,6-8\%, serta kadar serat pangan yang tinggi yaitu 8-1,5\% sehingga dapat dikatagorikan makanan sehat.

Budidaya jamur tiram yang berkaitan dengan pengimplementasian bioteknologi konvensional sehingga dapat menjadi sajian yang pas ketika diterapkan pada saat perkuliahan matakuliah bioteknologi. Selain itu matakuliah yang dapat diterapkan lainnya yaitu kewirausahaan biologi. Sajian-sajian matakuliah tersebut termuat pada tadris biologi Universitas Negeri Islam Antasari Banjarmasin.

Tadris Biologi merupakan prodi baru dari Universitas Islam Negeri Antasari yang berdiri sejak tahun 2017. Berdasarkan hasil observasi, tadris biologi sudah memiliki tiga (3) angkatan mahasiswa dengan jumlah peminat yg semakin meningkat setiap tahunnya. Sesuai dengan buku kurikulum fakultas tarbiyah dan keguruan Universitas Islam Negeri (UIN) Antasari (2018) tadris biologi memiliki sajian matakuliah dengan jumlah 103 SKS, dan memiliki matakuliah khas yang berbeda dari prodi lain yaitu pada bagian matakuliah kewirausahaan biologi.

Berdasarkan wawancara dengan ketua tadris biologi, tujuan disajikannya matakuliah Kewirausahaan biologi yaitu agar mahasiswa memiliki ciri khas produk yang akan diimplementasikan pada saat berwirausaha dengan berbasis biologi. Seperti contohnya usaha nata de coco dari kelapa, nata de coco dari lidah buaya, tape, tempe, tahu, jamur tiram dan masih banyak lagi. Selain itu, berdasarkan buku kurikulum (2018) tadris biologi mempersipakan lulusannya sesuai kompetensi tujuan, salah satunya yaitu sebagai wirausahawan pada bidang berbasis biologi maupun pendidikan biologi. Oleh sebab itu budidya jamur tiram merupakan dua pengaplikasian mata kuliah sajian pada tadris biologi, yaitu bioteknologi dan kemudian hasilnya dapat dipasarkan (produk khas biologi) berdasarkan matakuliah kewirausaahan biologi.

Selain itu budidaya jamur tiram sudah banyak digeluti masyarakat luas dengan prospek kedepannya yang sangat baik. Sesuai dengan pernyataan oleh Umniyati, dkk (2013) budidaya jamur tiram sangat mudah dilakukan dan dapat membantu meningkatkan ekonomi masyarakat khususnya bagi masyarakat korban erupsi merapi di dusun pandan Sleman DIY.

Berdasarkan penerapan budidaya jamur tiram sebelumnya yang sudah dilaksanakan dari beberapa peneliti memanfaatkan limbah hasil produksi pertanian seperti sekam padi. Suparti \& Lismiyati (2015) tentang produktivitas jamur tiram putih (pleurotus ostreatus) pada media limbah sekam pada dan daun pisang kering sebagai media alternatif, Daud (2013) Budidaya Jamur Tiram putih (Pleurotus ostreatus) menggunakan limbah kayu dan sekam padi, serta penelitian dari Muchsin (2017) tentang pengaruh penambahan sekam padi dan bekatul terhadap pertumbuhan dan hasil jamur tiram putih (Pleurotus ostreatus).

Berdasarkan hasil survei, pada lokasi di Kabupaten Banjar Kecamatan Gambut merupakn wilayah pertanian yang banyak menghasilkan ampas gabah berupa sekam padi yang menggunung namun belum pernah dipergunakan untuk pemanfaatan budidaya jamur tiram. Oleh sebab itu kami selaku dosen tadris biologi sekaligus fasilitator, tertarik ingin melaksanakan pengabdian kepada para mahasiswa tadris biologi dengan judul pengabdian yaitu "Pelatihan Budidaya jamur tiram (Pleourotus ostreatus var florida) untuk mahasiswa tadris biologi sebagai pendukung matakuliah bioteknologi dan kewirausahaan biologi".

\section{B. PELAKSAAN DAN METODE}

Adapun tahapan alur dalam pengabdian budidaya jamur tiram tersebut adalah sebagai berikut:

(1) Penyuluhan: melakukan penyuluhan secara daring dengan webinar online tentang Budidaya jamur tiram sebagai pengaplikasian matakuliah Bioteknologi dan kewirausahaan biologi dengan diikuti Semua mahasiswa tadris biologi dan peserta dari masyarakat umum. (2) Persiapan: melakukan pembentukan panitia untuk kegiatan lanjutan yaitu pelatihan budidaya jamur tiram dan implementasi dalam kewirausahaan yaitu 5 Panitia dari dosen sebagai tim pemantau kegiatan secara daring dan perekrutan 13 mahasiswa tadris biologi sebagai peserta pelatihan yang berdomisili di Banjarmasin mengingat pelaksanaan dilakukan pada pandemi covid-19 kemudian melakukan pembelian alat dan bahan serta mengurus ijin pendirian "Rumah Jamur". (3) Pelaksanaan 1: pelaksanaan budidaya jamur tiram serta pengimplementasian matakuliah bioteknologi yang diikuti 13 mahasiswa berdomisili di Banjarmasin yang berpartisipasi mengingat kondisi pelaksanaan pada saat pandemic Covid-19. (4) Pelaksanaan 2: pengimplementasian matakuliah kewirausaahaan biologi dengan menjual produk berkhas biologi yaitu seperti jamur tiram mentah, jamur tiram dan pelaksanaan pendampingan sejawat oleh tim kader di rumah jamur yang diikuti oleh 13 orang mahasiswa yang berdomisili di Banjarmasin membantu dalam tahap pelaksanaan kedua ini dengan melakukan pendampingan sejawat kepada mahasiswa tadris biologi. (5) Monitoring serta evaluasi kegiatan: monitoring serta evaluasi kegiatan yang dilakukan oleh Panitia dan fasilitator sebagai pihak yang membantu pendampingan memonitoring serta evaluasi yang juga dibantu narasumber.

\section{HASIL DAN PEMBAHASAN}

Pelaksanaan kegiatan dilakukan pada saat pandemi covid-19, yang mana kondisi tersebut mengharuskan masyarakat untuk jaga jarak, mengutamakan protokol kesehatan dan menghindari membuat 
kerumunan. Kegiatan dilaksanakan secara daring (dalam jaringan) dan luring (luar jaringan), dengan rancangan daring dimulai dari webinar online yang pesertanya terdiri dari mahasiswa tadris biologi dan terbuka untuk umum. Kemudian dilanjurkan luring yaitu pelatihan dengan peserta 13 mahasiswa yang berdomisili di kota Banjarmasin.

Penjaringan 13 peserta tersebut berdasarkan lokasi tempat tinggal dan wajib mahasiswa tadris biologi UIN Antasari Banjarmasin. Adapun tujuan pengkaderan 13 peserta tersbut yaitu: (1) untuk membantu perawatan jamur tiram yang ada di rumah jamur yang akan didirikan di lingkungan kampus UIN Antasari sebagai sarana belajar bioteknologi. (2) untuk membantu mengedukasi mahasiswa lain tentang cara budidaya jamur tiram yang baik dan benar. (3) untuk membantu melatih mahasiswa lain dalam perawatan budidaya jamur tiram. (4) untuk membantu mengembangkan kreasi hasil jamur tiram dalam bidang kewirausahaan. (5). untuk membantu mengelola jamur tiram yang ada di rumah jamur tiram . Setelah tahap pengkaderan berlangsung, para peserta diberi bekal 5-10 buah baglog jamur tiram untuk dibudidayakan di rumah masing-masing dengan perawatan sesuai arahan dari narasumber. Selama pengkaderan, mahasiswa tetap dipantau melalui form online untuk melaporkan kemajuan perkembangan jamur tiram yang mereka budidayakan di rumah masing-masing. Kemajuan perkembangan dilaporkan melalui link seminggu sekali setiap hari senin.

Pelaksanaan pelatihan dilaksanakan secara daring maupun luring, tujuannya yaitu agar penyuluhan tentang budidaya jamur tiram tetap tersampaikan meski dalam kondisi wabah covid-19. Adapun deskripsi pelaksanaan yang dilakukan dibahas secara terinci sebagai berikut:

\section{a. Daring (dalam jaringan)}

Pelatihan dimulai dengan penyuluhan secara daring melalui webinar online, dengan kegiatan dibantu secara jarak jauh oleh mahasiswa tadris biologi dan dosen tadris biologi. Perekrutan peserta dilakukan secara online dengan peserta dari mahasiwa tadris biologi dan terbuka untuk umum. Tujuan dilaksanakannya webinar online yaitu memberi informasi dan gambaran tentang tema pengabdian yaitu "pelatihan budidaya jamur tiram untuk mahasiswa tadris biologi sebagai pendukung matakuliah bioteknologi dan kewirausahaan biologi". Sesuai dengan tema tersebut, narasumber dicari berdasarkan keahlian, adapun narasumbernya yaitu dosen UIN Antasari pengampu matakuliah bioteknologi ibu Nida Humaida, M.Si, founder budidaya jamur tiram rumah jamur bintang hati ibu Ir Yuniar ellyana, dengan keynote speaker dari kepala UPT. Pengembangan kewirausahaan dan karier UIN Antasari Banjarmasin ibu Raden Yani Gusriani, SE.,MM . Webinar dilaksanakan pada hari kamis, 23 Juli 2020 pukul 10.00-11.30 dengan diikuti peserta terbuka untuk umum dan diwajibkan mahasiswa tadris biologi. Sebelum mengikuti webinar wajib mengisi link untuk pendataan peserta. Peserta beragam dari berbagai kalangan.

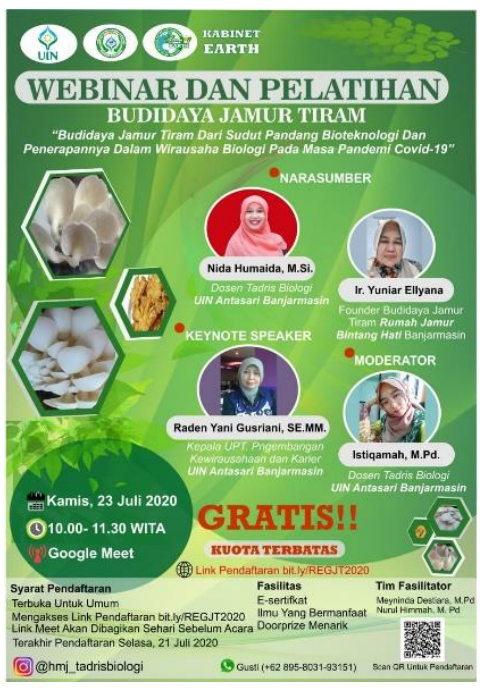

Gambar 1. Flyer webinar

Terdata ada 175 peserta yang registrasi pada peatihan webinar jamur tiram dari berbagai kalangan dan berbagai daerah. Ketika pelaksanaan beralangsung webinar mendapat sangat banyak respon dari peserta yang ingin berdiskusi terkait budidaya jamur tiram dan cara mengembangkannya menjadi berbagai olahan. Pelaksanaan webinar dibantu oleh 5 orang asisten penelitian dari kalangan dosen dan mahasiswa. Pelaksanaan webinar bertujuan utnuk penyuluhan kepada masyarakat luas dan mahasiswa tadris biologi sebagai peserta wajib. 


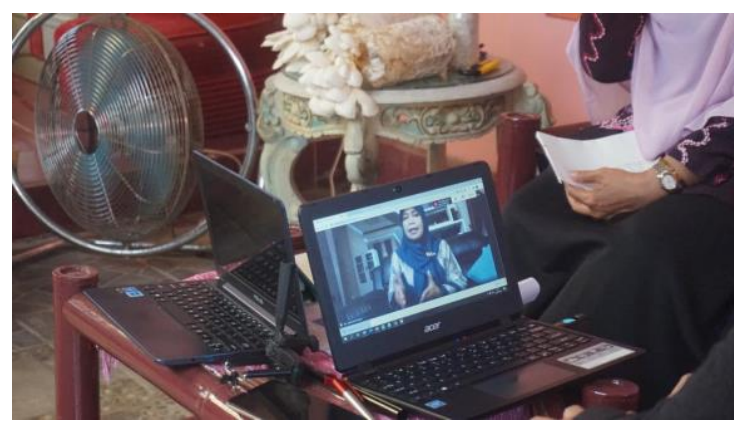

Gambar 2. Memantau pelaksanaan webinar sebelum melanjutkan pelatihan secara luring

Foto tersebut merupakan pemaparan dari keynote speaker yaitu ibu Raden Yani Gusriani. Sebelum dipaparkan narasumber, beliau memaparkan bahwa pentingnya berwirausaha dikalangan mahasiswa apalagi dalam kondisi saat ini. Setelah itu dilanjutkan kegiatan yang dipaparkan oleh para narasumbernarasumber. Setelah kegiatan tersebut selesai maka dilanjutkan penyerahan sertifikat dan cenderamata untuk narasumber, moderator dan keynote speaker.

Kegitan webinar berikut digandeng sama himpunan mahasiswa jurusan (HMJ) prodi tadris Biologi, agar kedepannya ketika pendirian rumah jamur akan dihibahkan kepada HMJ untuk mengelolanya dengan dibantu oleh tim kader. Tahap selanjutnya setelah webinar yaitu pelatihan tatap muka yang dibatasi hanya kepada 13 mahasiswa yang berdomisili di kota Banjarmasin. Pelatihan dilanjutkan di salah satu rumah Narasumber yaitu ibu IR. Yuniar Ellyana yangbernama rumah jamur tiram bintang hati bertempat di sultan adam Kota Banjarmasin.

\section{b. Luring (luar jaringan)}

Pelatihan utama dilaksanakan di tempat narasumber founder rumah jamur tiram bintang hati yaitu ibu Ir Yuniar Ellyana. Pelatihan dilaksanakan setelah dilaksanakannya webinar online.

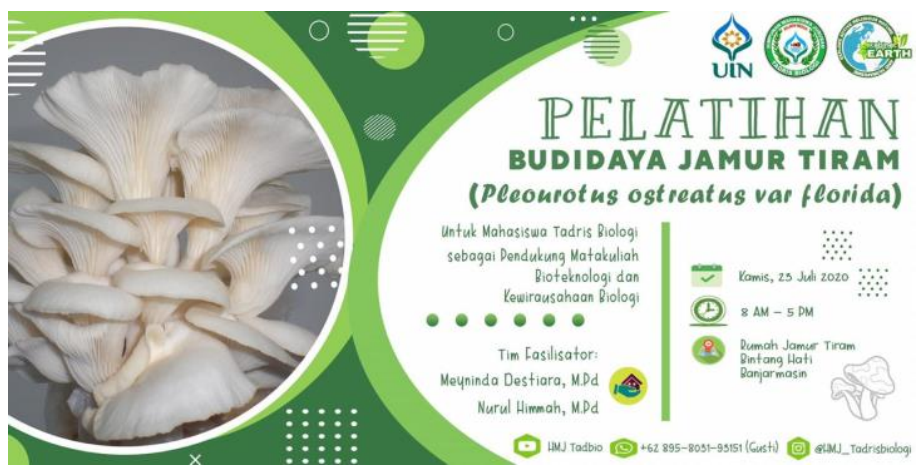

Gambar 3. Spanduk pelatihan

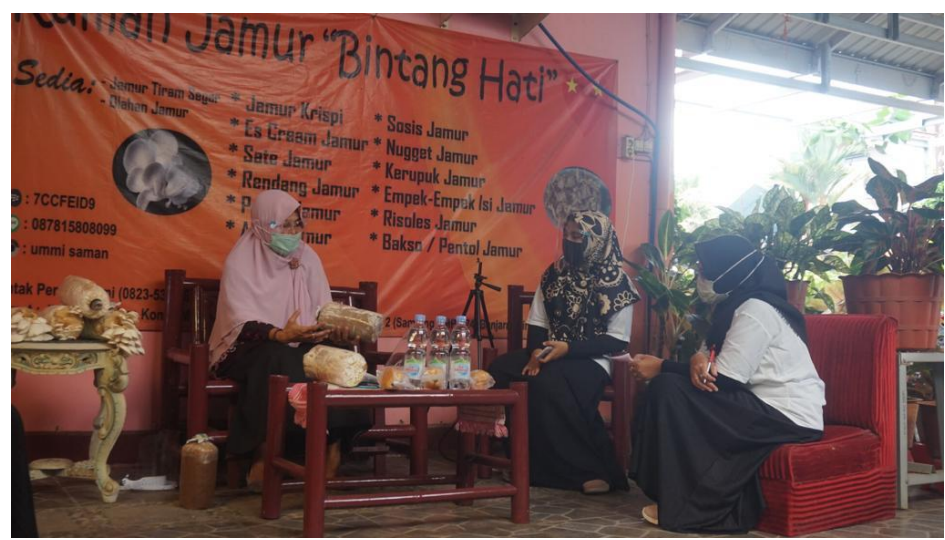

Gambar 4. Foto kegiatan pelatihan yang sedang berlangsung dipaparkan oleh narasumber 
Kondisi tempat pelatihan begitu mendukung untuk kegiatan yang sangat terbatas, dengan dilengkapi protocol kesehatan dan menjaga jarak posisi. Seperti yang terlihat pada foto kegiatan di bawah ini:

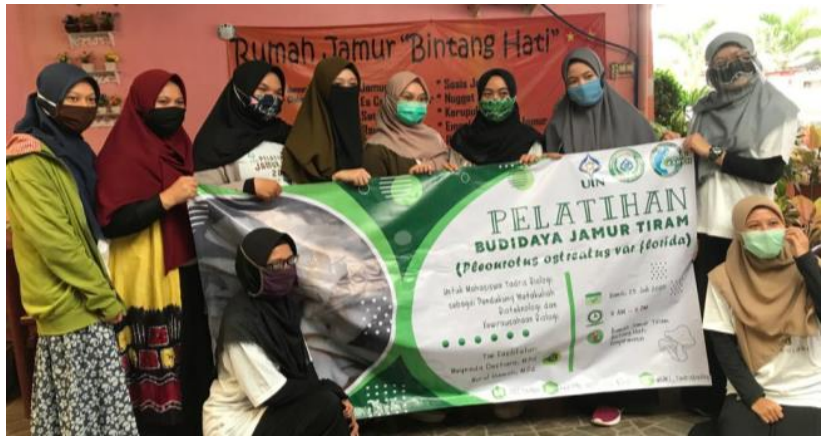

Gambar 5. Foto kegiatan pelatihan yang berlangsung

Setelah kegiatan pelatihan selesai, pembagian baglog jamur tiram untuk dibudidayakan para peserta di rumah masing-masing dengan mendapat arahan dari narasamber. Baglog yang dirawat berjumlah 5-10 buah, untuk pemantauan kegiatan dari rumah saja dibagikan instrumen berupa form yang akan diisi para peserta setiap satu minggu sekali tentang kemajuan perkembangan jamur tiram.

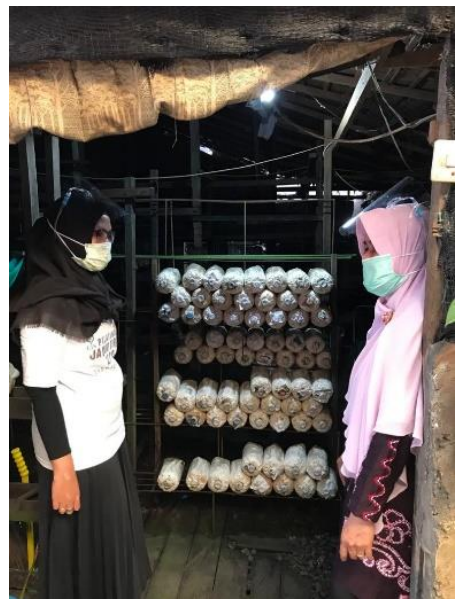

Gambar 6. Baglog jamur tiram siap untuk dibagikan kepada peserta

\section{c. Pelaporan Lanjutan Kegiatan Secara Daring}

Setelah selesai pelatihan, peserta masing-masing membudidayakan jamur tiram di rumah masingmasing dengan memberikan laporan secara online dengan form yang sudah disiapkan. Pelaporan dilakuan setiap minggu pada hari senin tentang perkembangan pemantauan jamur tiram. Setelah tahap pelaporan akan dianalisis dan dibahas pada whatsapp grup yang dipandu oleh fasilitator dan narasumber, ketika pada pelatihan di rumah aja mendapat kendala dan kebingungan. Sehingga kegiatan pelatihan ini selalu dilakukan evaluasi setiap minggunya terkait kemajuan budidaya mandiri.

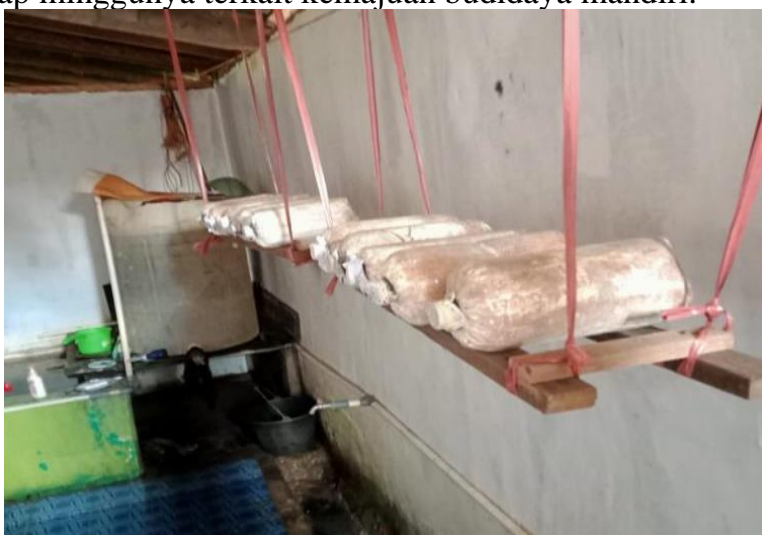

Gambar 7. Dokumentasi salah satu peserta yang melakukan budidaya secara mandiri di rumah aja 


\section{d. Lanjutan Pelaksanaan Pengabdian (Rumah Jamur)}

Pelaksanaan pelatihan jamur tiram dilaksankan berkelanjutan dengan mendirikan rumah jamur tiram di lingkungan fakultas tarbiya dan keguruan. Tujuan pendirian rumah jamur sendiri yaitu sebagai tempat praktikum bioteknologi dan untuk melanjutkan budidaya jamur tiram untuk dihibahkan kepada HMJ kemudian dikembangkan oleh tim kader yang ada 13 orang tersebut. Menindak lanjuti pendirian rumah jamur tiram, tim fasilitiator menemui atasan fakultas tarbiyah dan keguruan terkait perizinan mendirikan lahan. Setelah mendapat rekomendasi tim fasilitator menghitung prediksi pembangunan rumah jamur tiram. Setelah selesai keluar surat izin, tim fasilitator kembali mengukur dan mengira pendirian rumah jamur dibantu oleh tim lapangan.

\section{e. Output dan Outcome}

Pengabdian merupakan hal yang berkaitan dengan output dan outcome, seperti yang sudah dipaparkan sebelumnya pada output yang dilaksnakan adalah penyuluhan dilanjutkan dengan pelatihan jamur tiram secara mandiri dan sampai pada tahap pelaksanaan pendirian rumah jamur untuk memfasilitasi mahasiswa memahami bioteknologi dibidang budidaya jamur tiram. Outcome yang didapatkan para peserta webinar seperti ilmu yang bernanfaat, kemudian dilanjutkan pelatihan yang dilaksanakan secara luring kepada 13 tim kader. Sehingga kedepannya ketika wabah sudah mereda mereka dapat membimbing mahasiswa lain untuk mengelola rumah jamur tiram.

\section{f. Faktor Pendukung Dan Penghambat Kegiatan}

Kegiatan pengabdian ini menunjukkan keberhasilan apabila dalam prosesnya terjadi perubahanperubahan dalam membangun pengetahuan dan keterampilan secara mandiri dalam mengimplementasikan budidaya jamur tiram. Adapun beberapa indikator pencapaian kegiatan pengabdian pada ini adalah sebagai berikut: (1) Kehadiran seluruh peserta dalam pembelajaran mencapai 100\%. (2) Partisipasi aktif sebagian besar peserta dengan mengajukan pertanyaan substantif dan teknis dalam proses pembelajaran. (3) Keterlibatan dalam kegiatan pelatihan secara luring. (4) Melakukan monitoring setiap minggu tentang perkembangan dan dibahas kembali jika dalam melakukan perawatan jamur tiram mengalami kekeluruan. Beberapa faktor pendukung dan hambatan yang dialami dalam pelaksanaan pengabdian pada masyarakat adalah sebagai berikut : (1) Pelaksanaan budidaya jamur tiram dalam kondisi pandemi covid-19 sehingga pada pelaksanaannya hanya terbatas untuk mahasiswa yang berdomisili di Banjarmasin saja. (2) Pelaksanaan monitoring yang kadang terkendala kesibukan masingmasing individu sehingga lupa mensubmit kemajuan, namun hal ini bukan penghambat secara dasar dalam kegiatan. (3) Adanya diskusi online kembali dengan tim pemantau (monitoring) sehingga menambah pemahaman tim kader dalam merawat jamur tiram dengan baik dan benar.

\section{g. Keberlanjutan program}

Keberlanjutan dari program pelatihan budidaya jamur tiram ini adalah memberikan fasilitas berupa rumah jamur untuk mahasiswa tadris biologi. Tujuan pendirian rumah jamur yaitu untuk memfasilitasi mahasiswa dalam melaksanakan praktik bioteknologi konvensional sekaligus dapat menjual hasil budidaya dengan mengimplementasikan tujuan pengabdian berikutnya yaitu kewirausahaan biologi.

\section{PENUTUP}

\section{Simpulan}

Pelaksanaan pengabdian kepada masyarakat berbasis program studi berhasil dilaksanakan meskipun dalam kondisi pandemi covid-19, kegiatan dilaksanakan secara 2 arah yaitu dengan daring (dalam jaringan) dengan mengadakan penyuluhan melalui kegiatan webinar dan luring (luar jaringan) dengan peserta terbatas dan direkrut sebagai tim kader budidaya jamur tiram

\section{Saran}

Saran untuk tindak lanjut pelatihan adalah mengadakan skala besar pelatihan jamur tiram kepada seluruh angkatan mahasiswa biologi dengan harapan dapat melakukan inovasi dalam produk jamur tiram kedepannya. Seperti dibuat sate jamur tiram, ice cream jamur tiram, dan sebagainya. Sehingga kedepannya pelatihan ini tidak hanya sebatas pembudidayaan saja namun juga pengimplementasian besar membuat produk terbaharukan

\section{E. DAFTAR PUSTAKA}

Alexs, M. 2011. Untung Besar Budi Daya Aneka Jamur, Pustaka Baru Press, Yogyakarta.

Daud Muhammad. 2013. Budidaya Jamur Tiram Putih (Pleurotus ostreatus) menggunakan limbah kayu dan sekam padi. 
Donowati, Tjokrokusumo, dkk. 2015. Diversifikasi produk olahan jamur tiram (Pleurotus ostreatus) sebagai makanan sehat. Vol. 1 No. 8. Peos Sem Nas Masy Biodiv Indon

Muchsin, Ali Yazid., Wisnu Eko Murdiono dan Moch. Dawam Maghfoer. 2017. PengaruhPenambahan Sekam Padi dan Bekatul Terhadap Pertumbuhan dan Hasil Jamur Tiram Putih (Pleurotus ostreatus). PLANTROPICA Journal of Agriculture al Science. 30-38.

Muchtadi, Dedy. 2010. Teknik Ealuasi Nilai Gizi Protein. Bandung: Penerbit Alfabeta.

Suparti dan Lismiyati Marfuah. 2015. Produktivitas Jamur Tiram Putih (Pleurotus ostreatus) pada Media Limbah Sekam Padi dan Daun Pisang Kering sebagai Media Alternatif. J: Bioeksperimen. Universitas Muhammadiyah Surakarta. Jawa Tengah (1(2): 37-38)

Umniyati Siti, dkk. 2013. Budidaya Jamur Tiram (Pleuretus.. Sp) Sebagai Alternatif Usaha Bagi Masyarakat Korban Erupsi Merapi di Dusun Pandan,Wukirsari, Cangkirangan, Sleman DIY. Vol.17 